\title{
WORKING SPEAKERS IN WHITMAN AND HOPKINS
}

\author{
ERnest Fontana
}

IN his LetTer to Robert BRIDges, dated October 18, 1882, Gerard Manley Hopkins confesses that though "I cannot have read more than a half dozen pieces at most" of Whitman's poetry "I may as well say what I should not otherwise have said, that I always knew in my heart Walt Whitman's mind to be more like my own than any man's living. As he is a very great scoundrel this is not a pleasant confession. And this makes me the more desirous to read him and the more determined that I will not." This is an extraordinary admission and one fraught with anxiety. It is, first of all, a difficult and painful admission; "I should not otherwise have said." It comes from Hopkins's depths and has been, hitherto, a secret; "I always knew in my heart." To admit this affinity is like revealing a sin to a confessor; "this is not a pleasant confession." This deep, hidden affinity is seductive and a source of pleasure; "this makes me the more desirous to read him." An earlier reference to Whitman (January 29, 1879) is less colored with the connotations of wrongdoing and confession. "All the world, so to speak, approves of charity and the corporal works of mercy, though all the world does not practise what it approves of. Even Walt Whitman nurses the sick."2 Here, however, the word even suggests it is surprising that a "scoundrel" like Whitman would perform "the corporal works of mercy." This reference demonstrates that Hopkins was familiar with Whitman's "Wound-Dresser" from Drum-Taps (1865) and the fourth edition of Leaves of Grass (1867).

In this essay, I am not primarily arguing influence, though on the other hand I'm not denying the strong likelihood of Whitman's influence on Hopkins. ${ }^{3}$ What I shall be arguing is more interesting and more significant. I am arguing that Whitman and Hopkins are among the first English language poets to represent and dramatize a first person lyric voice or persona that is foregrounded in their poems as someone who is not primarily a poet but someone engaged in ordinary labor. In the poems I shall consider, the utterance is not constructed or presented as that of a poet, but instead as the utterance of a wound-dresser or nurse in Whitman or as the utterance of a working priest in Hopkins. What is unusual about these poems in which the poet is creating the illusion that he himself is speaking, poems in which the poet appears to be imitating himself, is that the poet-speaker is dramatized as performing a specific 
act of labor. In the case of Whitman, we, of course, know that he was a hospital visitor in New York and Washington during the Civil War and in the case of Hopkins that he was an ordained Jesuit priest. But it is not the biographical actuality that is significant here, but the dramatization of what we know to be historical fact in the constructed poetic utterances of both poets.

Since the Renaissance, in those poems in which the poet appears to be imitating himself, the voice that is constructed or dramatized is the voice of a poet. It is an ideal version of the actual Shakespeare or Keats who speaks in The Sonnets and Odes respectively. If the poet is to dramatize himself in a role other than that of poet, the most conventional mode would be that of lover, not, in the case of Shakespeare, for example, as working actor. In those poems in which a worker is presented, as in Wordsworth's "The Solitary Reaper" or his "Resolution and Independence," the speaker remembers and reflects upon an accidental encounter with a worker other than himself. In Wordsworth's case, the focus is on the effect of the worker on a poet, not on another worker. One might argue that a poet is a worker. But what is emphasized in the hegemonic poetic tradition, as in the case of the two Wordsworth poems, is not the poet as worker but as visionary consciousness. It is by retaining the memory of the reaper singing in an unintelligible language that the speaker-poet in "The Solitary Reaper" writes his poem. The speaker's voice in this poem as in "Resolution and Independence" is that of a peripatetic consciousness that is inspired into utterance by the remembrance of encounters with solitary reapers and leech-gatherers. The $I$ in these poems does not work, but contemplates, remembers, envisions, and imagines:

Whate'er the theme, the maiden sang

As if her song could have no ending;

I saw her singing at her work,

And o'er the sickle bending;-

I listened, motionless and still;

And, as I mounted up the hill,

The music in my heart I bore,

Long after it was heard no more.

While he was talking thus, the lonely place,

The old Man's shape and speech-all troubled me:

In my mind's eye-I seemed to see him pace

About the weary moors continually,

Wandering about alone and silently.

Because the speaker's consciousness in these poems is presented as removed from the particular physical and economic actualities of work, the speaker's voice assumes a normative universality. ${ }^{4}$ The reader can identify with the speaker's voice in Wordsworth's two poems because 
the speaker's voice is not disfigured by the particular historical, quotidian details of work or labor. Although the subject of these poems may be quotidian labor, the poet-speaker appears to transform it through the power of imagination into symbols and signs; "in my mind's eye I seemed to see him pace / About the weary moors continually / Wandering about alone and silently." 5

One might argue that working speakers existed in English language poetry prior to Whitman and Hopkins. For example, the anonymous broadside, "The Bury New Loom," first published in 1804, presents us with a speaker who is "a good joiner by trade" and a maker of hand looms. ${ }^{6}$ Nevertheless, poems by working class poets or self-taught poets most often avoid the direct representation of the quotidian details of the poet-worker's work. As Brian Maidment has shown, self-taught working class poets in the nineteenth century avoided the particulars of the working class city and even particular instances of suffering and oppression. ${ }^{7}$ The most politically effective poems, such as Ernest Jones's "Song of the Low" (1852), ${ }^{8}$ represent the generalized collective grievances of an entire class not the particular experience of an individual worker. Dominated by an exalted Romantic ideal of poetry, working class poets, as Vicinus shows, "felt an obligation to show a world where beauty was the norm," rather than the particular details of their working life. ${ }^{10}$

Even John Clare who was both an agricultural laborer and ambitious poet eschews representing himself as a speaker engaged in agricultural labor. Most often in Clare it is leisure, the time between labor, that is spoken of by his speakers, either in impersonated mask lyrics such as "The Woodcutter's Night Song" $(1821)^{11}$ or in self-representing lyrics such as "Labour's Leisure" and "Nutting" from The Rural Muse (1835). ${ }^{12}$ Unlike the middle class nurse or priest for whom work is a meaningful service for a palpable other, agricultural labor does not so directly and palpably provide meaning to the worker. For an agricultural laborer such as Clare, particularly one seeking through poetry to escape his class, leisure would inevitably be more meaningful than work. It is not surprising, therefore, that Clare's most detailed evocations of agricultural labor are from the point of view of leisured spectator rather than participant, such as "Harvest Morning" (1820) and the originally unpublished "Haymaking." 13 In the latter, Clare assumes the Wordsworthian persona of spectator and visionary for whom the work of others is an aesthetic datum to be consumed and transformed by poetry:

There's nothing sounds so welcome

As their singing at their toil

Sweet maidens with tan'd faces

And bosoms fit to broil 
And its beautiful to look on

How the hay-cleared meadow lies

How the sun pours down his welcome heat

Like gold from yonder skies

It is this poetic discourse of normative, visionary universality that Whitman and Hopkins rupture. Whitman's rupture appears to have been derived from his work as hospital visitor and volunteer nurse in New York Hospital during 1861-2, visiting and attending young men wounded in the Civil War. It is during this time that he wrote his prose Memoranda During the War which he attempted, unsuccessfully, to publish in $1863 .{ }^{14}$ In this text America itself seemed "one vast central Hospital," in which the poet records his ministrations as healer and "on-the-spot observations." "It is the persona of "the poet healer whose agonies are recollected in tranquility" that will become the unifying element of Drum-Taps. ${ }^{16}$

In "A March in the Ranks Hard-Prest, and the Road Unknown" from Drum-Taps, Whitman's speaker is both a soldier and nurse. $\mathrm{He}$ presents in a cinematic sequence the present tense sensorial-emotional experience of entering "a large old church at the crossing roads, now an impromptu hospital." 17 By the light of "one great pitchy stationary torch with wild red flame" he sees on the floor "a soldier, a mere lad," shot in the abdomen, "in danger of bleeding to death." What is presented is not only what the speaker saw and smelled- "surgeons operating, attendants holding lights, the smell of ether, the odor of blood" -but the speaker as active agent. "I stanch the blood temporarily, (the youngster's face is white as a lily);" "I bend to the dying lad, his eyes open, a half smile he gives me."

The active poet-speaker is also presented in "A Sight in Camp in the Daybreak Gray and Dim," based on Whitman's memories of his visit to his soldier brother George at Falmouth, Virginia in $1862 .{ }^{18}$ Here the speaker enters a tent and beholds the corpses of three soldiers "on stretchers lying, brought out there untended lying." The speaker halts and, after lifting the blankets that cover them, observes first an "elderly man so gaunt and grim" and then "a sweet boy with cheeks yet blooming." But it is the third, "a face, nor child, nor old, very calm, as of beautiful yellow ivory" in whom the speaker sees "the face of the Christ himself / Dead and divine brother of all, and here again he lies." In his role as healer-ministrant the speaker receives an unexpected revelation of the redemptive presence of Christ in the face of an obscure, martyred victim of war. The healer is, momentarily, healed by his vision.

In "The Wound-Dresser" Whitman draws directly on his experience as an unpaid "Soldier Missionary" at Washington's Armory Square Hospital, involved in "visiting the sick and wounded" and "aiding 
surgeons on the battlefield and elsewhere in the care and conveyance of the wounded to hospitals." 19 The speaker in "The Wound-Dresser" is an old man, remembering for "the young men and maidens that love me" his experience among "the mightiest armies of earth" as a soldier and nurse. It is the latter role the poem stresses. For example, the speaker remembers entering the door of a hospital ward or tent:

Bearing the bandages, water and sponge,

Straight and swift to my wounded I go,

Where they lie on the ground after the battle brought in,

Where their priceless blood reddens the grass the ground,

Or to the rows of the hospital tent, or under the roofd hospital,

To the long rows of cots up and down each side I return,

To each and all one after another I draw near, not one do I miss,

An attendant follows holding a tray, he carries a refuse pail,

Soon to be fill'd with clotted rags and blood, emptied, and fill'd again.

The past becomes present as the speaker remembers treating specific individuals; "the crush'd head I dress, (poor crazed hand tear not the bandage away)." The speaker is not presented as a poet but a worker, engaged in the work of healing the wounded and maimed:

From the stump of the arm, the amputated hand,

I undo the clotted lint, remove the slough, wash off the matter and blood,

Back on his pillow the soldier bends with curv'd neck and side-falling head,

His eyes are closed, his face is pale, he dares not look on the bloody stump,

And has not yet look'd on it.

The memory of his past work as wound-dresser leads the speaker into a dreamlike, visionary trance. The nurse-speaker is transformed into a nurse-lover. The physical details of the wound-dresser's work are a displaced rendering of a powerful erotic experience that is the source of the speaker's visionary trance and lyric ardor:

Thus in silence in dreams' projections,

Returning, resuming, I thread my way through the hospitals,

The hurt and wounded I pacify with soothing hand,

I sit by the restless all the dark night, some are so young,

Some suffer so much, I recall the experience sweet and sad,

(Many a soldier's loving arms about this neck have cross'd and rested.

Many a soldier's kiss dwells on these bearded lips.)

As his letter of January 29, 1879, indicates, Hopkins knew "The Wound-Dresser"- "Even Walt Whitman nurses the sick"- and read it not as a dramatic monologue but as a poem in the poet's own voice. It has even been suggested that these lines from "The Wound-Dresser" are echoed in Hopkins's "Felix Randal":"20 
One turns to me his appealing eyes-poor boy! I never knew you,

Yet I think I could not refuse this moment to die for you, if that would save you.

It is, however, not so much verbal and phrasal influence that concerns me here, but the remarkable parallelism between both Hopkins's "The Bugler's First Communion" and "Felix Randal" and the poems from Whitman's Drum-Taps, particularly "The Wound-Dresser," that we have examined above. The parallels, which may also be evidence of influence, lie in the innovative presentation by both poets of a speaker who is, simultaneously, an ideal representative of the poet's own voice and someone who is engaged in labor. Secondly, these poems express, openly in the case of Whitman and more guardedly in the case of Hopkins, homoerotic feeling that in both poets is displaced to and dramatized through specific gestures of their speaker's labor.

"The Bugler's First Communion" was written at Oxford on July 27, 1879, six months after Hopkins's epistolary reference to Whitman's "The Wound-Dresser." ${ }^{21}$ Hopkins at this time was serving as curate of St. Aloysius Church at Oxford and the subject of the poem was inspired by a bugler boy from Cawley barracks who received his first communion from Hopkins at St. Aloysius.

The poem begins with the speaker remembering the physical processes of giving to the adolescent bugler the Eucharistic host or "housel." The speaker, retrospectively, admires the virginal manliness of the bugler who is referred to as "Christ's darling." The speaker then addresses the bugler's guardian angel, "forefending angel-warder," as an older fellow warrior who will protect the bugler from molestation. The angel is addressed in that most Whitmanesque word, comrade, which in both Drum-Taps and Calamus is the code word for male lovers: ${ }^{22}$

Frowning and forefending angel-warder

Squander the hell-rook ranks sally to molest him;

March, kind comrade abreast him;

Dress his days to a dextrous and starlight order. ${ }^{23}$

Although for the speaker the bugler is "Christ's darling" and the angel-warder's comrade, the speaker's heart also responds to the bugler's submission to his teaching, to his yielding "tender as a pushed peach":

How it does my heart good, visiting at that bleak hill,

When limber liquid youth, that to all I teach

Yields tender as a pushed peach,

Hies headstrong to its wellbeing of a self-wise self-will!

The fresh virginal and vernal docility of the bugler-" "fresh youth 
fretted in a bloom fall all portending / That sweet's sweeter ending" -is seen as prefiguring the freshness of the resurrected body, "Realm both Christ is heir to and there reigns." The poem ends with the speakerpriest remembering the prayer, part of his work as priest, that he has made to preserve "God's own Galahad" from molestation.

Recorded only, I have put my lips on pleas

Would brandle adamantine heaven with ride and jar, did

Prayer go disregarded. . . .

Not only does Hopkins present a speaker actively engaged in the quotidian labors of a priest-"Forth Christ from cupboard fetched" 24 -he also in "The Bugler's First Communion" appropriates Whitman's idea of comradeship, extending it to the relation between boy and angel, and by implication, boy and Christ - "Christ's darling, dauntless." The Christian devotional tradition that has privileged the relation of bridegroom and bride as metaphor for the relation of Christ and the soul-e.g. Donne's "Batter my heart, three-personed God," Christina Rossetti's "Advent," and Tennyson's "St. Agnes' Eve"-is thus unexpectedly and momentarily revised in "The Bugler's First Communion."

Hopkins's more sublimated masterpiece "Felix Randal" was written on April 28, 1880, nine months after "The Bugler's First Communion," in Liverpool where Hopkins worked among Irish immigrants as select preacher to St. Francis Xavier Church. ${ }^{25}$ Alfred Thomas has identified the actual name of the young farrier who died of pulmonary tuberculosis in April 1880 as Felix Spencer. ${ }^{26}$ Once again as in "The Wound-Dresser" and "The Bugler's First Communion" this sonnet presents a speaker who remembers, upon hearing of the death of Felix Randal, the quotidian details of his professional and pastoral relation with Randal, his "duty all ended." The speaker remembers giving Felix, broken by sickness, the Eucharist; "I had our sweet reprieve and ransom / Tendered to him." (Note the pun on tendered.) In the sestet of the sonnet, the speaker reflects on the reciprocity of the pastoral relation. With his tongue the speaker has comforted Felix; with his touch, in the ritual of Extreme Unction, he "had quenched thy tears," the tears that have, reciprocally, "touched my heart, child, Felix, poor Felix Randal." In his work as priest the speaker brought grace to Felix Randal, and in response, Felix Randal has brought grace to the priestpoet.

The similarity to Whitman's "A Sight in Camp in the Daybreak Gray and Dim" is striking. There the wound-dresser speaker was touched by the face of one of the dead soldiers - "a face, nor child, nor old, very calm, as of beautiful yellow ivory"-into seeing "the face of Christ himself." The speaker was suddenly given what is presented as a 
visionary experience. In Hopkins this reciprocity is constructed in less bombastic terms. What the priest-poet is given is not the privilege of vision, but ordinary, available grace.

The homoerotic sexual metaphor for the relation among the three primary figures in "The Bugler's First Communion" is not found in "Felix Randal." Although the work of the priest is a way of loving Felix Randal, whom he plangently addresses as if still alive as a bereaved lover, the relation between speaker and subject is one between equals -adult priest and adult farrier: a relation of authentic comradeship in contrast to the sublimated and spiritualized pederastry of "The Bugler's First Communion."

The concluding tercet of "Felix Randal" moves from the tenderly quotidian to the monumental and heroic. "The great grey drayhorse" with "his bright and battering sandal" is a figure of Christ as the energy that batters Felix through sickness, that breaks him, but that, paradoxically, through the mediation of sacramental grace bestowed by the priest-poet, mends him. If the drayhorse is a figure of Christ, it is a brilliant act of closure, since drayhorses are workhorses, pullers of drays or carts. Christ is not figured here as an aristocratic "stallion stalwart" as in "Hurrahing in Harvest," but instead as a powerful, but ordinary workhorse who triumphs over Felix with the shoes Felix has forged for him:

How far from then forethought of, all thy more boisterous years,

When thou at the random grim forge, powerful amidst peers,

Didst fettle for the great grey drayhorse his bright and battering sandal!

Thus in "Felix Randal" the poem's three personages are presented as workers: the farrier, the speaker-priest, and the drayhorse Christ.

Hopkins treats representative workers elsewhere in his poetry: in "Tom's Garland" the unemployed industrial worker and in "Harry Ploughman" the agricultural laborer. What is unusual about "The Bugler's First Communion" and "Felix Randal" is the presentation of the speaker as himself engaged in professional duty and labor rather than as a disembodied, normative consciousness. Hopkins, like Whitman in some of the lyrics of Drum-Taps, constructs a persona that is acting in the world, a persona that has put aside the privilege and the power of Romantic totalizing vision.

But what is equally interesting is that both poets depart from poetic tradition in order to represent sexual feeling. Eve Kosofsky Sedgwick has shown that because of Whitman the rigid separation in literature of homosocial and homoerotic feeling enforced since the mid-seventeenth century begins to soften. ${ }^{27}$ What Hopkins is able to learn from Whitman is that the physical and psychological reciprocity involved in the service worker's relation to his "patient" can assume an erotic aura. 
Thus the social relations of ordinary working life can be charged with an erotic aura not available to the poet for whom the erotic is removed from ordinary life and for whom it is, therefore, associated exclusively with situations that are explicitly sexual or amatory. What Hopkins learns from Whitman and demonstrates in "The Bugler's First Communion" and "Felix Randal" are the erotic possibilities of the ordinary, the contemporary, and quotidian, specifically of ordinary working life. ${ }^{28}$ Consequently homoerotic feeling, which in nineteenth-century poetry could not easily be presented explicitly unless historicized to ancient Greece or Rome as in Symonds's Ithocles or "Midnight at Baiae,"29 could be articulated by the poet representing himself not as lover or desirer, exclusively, but as working nurse or priest. Thus the homosocial reciprocity of male relations in both Whitman and Hopkins, dramatized in those poems where the speaker is an active worker, becomes the site of the displaced articulation of erotic feelings in situations that are non-sexual and non-amatory. By freeing the poet from the role of disembodied visionary consciousness Whitman and Hopkins not only work to democratize poetry but to eroticize it.

\section{Xavier University}

\section{NOTES}

1 The Letters of Gerard Manley Hopkins to Robert Bridges, ed. Claude Colleer Abbott (London: Oxford University Press, 1935), 1:155.

\section{Letters, 1:63.}

3 William Templeman's "Hopkins and Whitman: Evidence of Influence and Echoes," Philological Quarterly 33 (1954), 48-65, is a superficial treatment of the subject.

4 Whitman himself assumes this role in poems such as in Song of Myself (Section 12) and "Sparkles from the Wheel."

5 The Poetical Works of William Wordsworth, ed. E. DeSelincourt and Helen Darbishire (Oxford: The Clarendon Press, 1957), 3:77.

6 Reprinted in Martha Vicinus, The Industrial Muse (New York: Barnes and Noble, 1974), 40-41. This poem does not, however, create the illusion that the speaker is also the poet who wrote the utterance. This broadside is what Ralph Rader would identify as a "mask lyric," a stylized impersonation of representative emotions and attitudes; see "The Dramatic Monologue and Related Lyric Forms," Critical Inquiry 3 (1976), 131152. In this case the handy joiner's repair of the broken loom of his "dear lassie" is an extended metaphor for sexual intercourse. The details of the joiner's craft become interesting because of the bawdy analogies developed by the speaker, e.g., "Her lathe it went bang to and fro, my main treadle still kept in tune."

7 Brian Maidment, The Poorhouse Fugitives (Manchester: Carcenet, 1987), 150, 60. The same can be said of the late eighteenth-century milkwoman poet Anna Yearsley. Her poems, written under the influence of Young's and Collins's theories of natural inspiration, do not dramatize a speaker engaged in the quotidian particulars of work. See Moira 
Ferguson's "Resistance and Power in The Life and Writings of Ann Yearsley," Eighteenth Century Theory and Interpretation 27 (1986), 247-268.

8 Reprinted in Maidment, 44-46.

9 Vicinus, 147.

10 An exception is Joseph Skipsey who was a contemporary of Hopkins and Whitman. See Maidment 85, 93-94.

11 Poems by Fohn Clare, ed. Arthur Symons (London: Henry Frowde, 1908), 62.

12 Selected Poems and Prose of Fohn Clare, ed. Eric Robinson and Geoffrey Summerfield (London: Oxford University Press, 1967), 104, and Poems, 116.

13 The Later Poems of Fohn Clare, ed. Eric Robinson and David Powell (Oxford: Clarendon Press, 1984), 1:281.

14 Justin Kaplan, Walt Whitman: A Life (New York: Simon and Schuster, 1980), 278. The Memoranda were published in 1875.

15 Walt Whitman's Memoranda During the War and Death of Abraham Lincoln, ed. Roy Basler (Bloomington: Indiana University Press, 1962), 3-4.

16 Harold Aspiz, Walt Whitman and the Body Beautiful (Urbana: University of Illinois Press, 1980), 85.

17 All quotes from Whitman's poetry are from Leaves of Grass: Comprehensive Reader's Edition, ed. Harold Blodgett and Sculley Bradley (New York: New York University Press, 1965).

18 Aspiz, 87.

19 This charge is quoted in Kaplan, 275.

20 Eleanor Ruggles, Gerard Manley Hopkins, A Life (New York: W. W. Norton, 1944), 221-225.

21 Paul Mariani, A Commentary on the Complete Poems of Gerard Manley Hopkins (Ithaca: Cornell University Press, 1970), 146-147.

22 For example, “As Toilsome I Wander'd Virginia's Woods," which is separated from "The Wound-Dresser" by two poems of six lines each, ends with the speaker quoting an army tombstone in Virginia that has remained engraven in his memory, "Bold, cautious, true, and my loving comrade," and that evokes for the speaker an ideal of male love.

23 All quotes from Hopkins's poetry are from Poems and Prose, ed. W. H. Gardner (New York: Penguin Books, 1953).

24 Hopkins's quotidian realism should be distinguished from the parabolic presentation of the work of the priest in George Herbert's "Aaron."

25 Norman H. Mackenzie, A Reader's Guide to Gerard Manley Hopkins (Ithaca: Cornell University Press, 1983), viii.

26 Cited by Mackenzie, 136.

27 Eve Kosofsky Sedgwick, Between Men: English Literature and Male Homosocial Desire (New York: Columbia University Press, 1985). Curiously, Sedgwick does not treat Hopkins in her chapter on "Toward the Twentieth Century: Readers of Whitman." 
28 I am thus in disagreement with Linda Dowling who writes "it is yet difficult to trace in Hopkins's poetry the unconscious presence of any 'homosexual' code that might join him to the poet of "Calamus" "; see "Ruskin's Pied Beauty and the Constitution of a 'Homosexual Code' ," Victorian Newsletter no. 75 (1989), 1-8.

29 Reprinted in The Penguin Book of Homosexual Verse, ed. Stephen Coote (New York: Penguin-Viking, 1986), 217-220. See Dowling on the uses of the historical fiction of the Dorians. 